\title{
Phatic Language in a Specific Culture Perspective in the Context of Internationalization of the Indonesian Language
}

\section{R. K. Rahardi}

Master Program of Indonesian Language and Literature Education, Department of Language and Art Education, Faculty of Teachers' Training and Education, Sanata Dharma University, Yogyakarta, Indonesia

\section{Abstract}

The main purpose of this study was to describe the form and meaning of phatic language from the perspective of a specific culture in the scope of language internationalization. The source of the data of this study was the speeches of the

Corresponding Author:

R. K. Rahardi

kunjana.rahardi@gmail.com

kunjana@usd.ac.id

Received: 6 April 2018

Accepted: 3 May 2018

Published: 26 July 2018

Publishing services provided by Knowledge $\mathrm{E}$

(c) R. K. Rahardi. This article is distributed under the terms of the Creative Commons

Attribution License, which

permits unrestricted use and

redistribution provided that the

original author and source are credited.

Selection and Peer-review under the responsibility of the ISLLE 2017 Conference Committee. society in various domains that contained manifestations of phatic language. The data were collected by employing the listening method and the speaking method according to the categories. Data analysis applied the contextual method and the distributional method. The outcomes of this phatic language study from the perspective of a specific culture will be useful for the following: (1) enriching the pragmatic knowledge that still needs to be increased in this country; (2) documenting the sociocultural richness of Indonesian society; (3) supporting the government's efforts to internationalize the Indonesian language.

Keywords: dignified language, Indonesian language internationalization, phatic language, specific culture

\section{Introduction}

Internationalization of the language is a mandate of Law number 24 of 2009, which in essence affirms that the government is responsible for improving the function of Indonesian language as an international language gradually, systematically, and continuously. In fact, the internationalization of languages is not only the responsibility of the government, but also of the entire Indonesian people. Internationalization of the language can be achieved when the Indonesian language has become a dignified language, one that is characterized by the establishment of standardization. 
This establishment is characterized by the possession of rules of conduct that enable the wider community, both locally and globally, to learn the language easily [1]. Various functions and interests can be accommodated with the dignified Indonesian language. The rules are not only linked to the standard language that is generally included in the descriptive and prescriptive grammar domain, but also other phenomena contained in the pragmatic realm $[2,3]$. Based on the studies undertaken, it must be acknowledged that the phenomenon of language in the pragmatic realm has not been fully elaborated in detail and depth until now.

The notion of a less than optimal pragmatic phenomenon not only occurs in the scope of the phenomenon, but also in the substance and depth of each of the phenomena described. Many of the pragmatic phenomena that have been described are deixes, implicatures, and language politeness [4]. The new pragmatic phenomena that in relative terms are not yet widely spoken are language impoliteness and phatic language $[2,5]$ These last two pragmatic phenomena have been sought by the authors through research done by the fund of the Directorate of Research and Community Service, Ministry of Technology Research and Higher Education, starting from 2015 till now.

The author wishes to affirm that pragmatic phenomena that have been widely practiced tend to be less extensive, sharp, and profound because research data tend to be based on Western language and cultural data. Meanwhile, the pragmatic phenomena that serve as the basis for formulating these rules are also present in the context of specific culture. In other words, there is a gap between pragmatic rules based on Western language data with rules based on languages in the context of a specific culture.

This short paper is intended to bridge the gap that occurred so that in the future synchronization is expected to occur between the pragmatic rules based on Western culture with a specific culture based. Moreover, now the surge of internationalization of Indonesian language is being strongly pursued. The golden opportunity to integrate the results of the study of pragmatic phenomena based on a specific culture that is full of local wisdom values into the internationalization context of Indonesian language should be widely practiced by Indonesian linguists.

The study of phatic language on the basis of a specific culture in this language internationalization vehicle stems from the phatic communion concept conveyed by Bronislaw Kaspar Malinowski, the British-Polish anthropologist, who in 1923 examined the living habits of people living in Trobriand $[1,6]$. In his research, this anthropologist gave birth to two functions of language, namely (1) a pragmatic function, and (2) a 
magical function. Furthermore, it should be emphasized that the term "phatic" comes from the Greek verb "to speak," while the term "communion" means "the creation of ties of union" [7]. The term "phatic communion" is defined as "establishing an atmosphere of sociability rather than communicating ideas."

Thus, it must be emphasized that the principal purpose of witchcraft is to build an atmosphere of togetherness, not to communicate ideas. Related to that, $[2,8]$ also described the term "communion," which refers to "the phenomenon of personal encounter; face to face two human figures." Symptoms of the encounter of the two human figures bring togetherness.

Thus, it is clear that the term "communion" is not the same as "communication," which essentially means "delivering information and ideas," which in Abercrombie is called "communication of thought" [7]. This linguist asserts that language does not merely function as a vehicle for communicating information, ideas, and thoughts, but more than that, language serves as a vehicle for making "others as neighbors to themselves."

The process of making others fellows for others is only possible when speakers and interlocutors are able and willing to work together to make others mutual. Cooperation to make others fellows is possible only because there is an "encounter" activity to build deals. This researcher's view is in line with the one delivered by Abercrombie, "ties of union" or kinship ties, i.e. togetherness in the encounter to build agreements [7].

"...to refer to communication between people which is not intended to seek or convey information but has the social function of establishing or maintaining social contact" [9]. They insist that the main purpose of phatic language is not "searching for information" and not "conveying information" but "building and maintaining social relations." So no doubt when someone meets his friend on the street, greetings like "hey... where to go" or "hey... how is it" are delivered casually by waving hands.

In the realm of education, among the lecturers who are walking to the classroom to teach can also be each other, "pagi...mau ngajar yo" (morning, going to tech yeah?), even though each already understands because both want to teach. Clearly visible from the example of the utterance delivered before, the ultimate goal is not to convey ideas, but to keep togetherness, and build social contact $[2,10]$. The framework of understanding of the phenomenon of phatic language as mentioned earlier is the framework of reference in conducting this pragmatic research. 


\section{Methods}

The methodological aspects of pragmatic research on phatic language in a specific culture base in the Indonesian internationalization medium are described as follows. The locational data source of this research was Indonesian speakers with a Javanese culture background. Sources of substantive data of this research were public-speaking remarks in various domains in which the data contains phatic language. Thus, it can be said that the data of this study were utterances that contained various forms and phatic pragmatic meaning.

The data were collected by applying the listening method, especially listening that involved speaking. The method is implemented with a number of techniques, both basic and advanced. The data analysis methods used were the extralingual method or the contextual method $[2,8]$. This method of analysis was also applied by replacing the basic techniques and advanced techniques. Furthermore, the method of serving the results of the analysis was an informal method, i.e. methods that did not replace symbols and certain formulas as commonly applied in formal presentation methods $[2,11]$.

\section{Results}

As mentioned in the previous section, the research of phatic language derived from data on the speeches used by citizens in the Indonesian language with a Javanese culture background. It is not unusual that in certain shoots, the language used was dominant in Javanese, not Indonesian. However, in the overall speech, the language vehicle used was the Indonesian language.

\section{Data 1}

Speaker: Niki ngeten, kula kalihan rencang diutus kalih dosen pados dato Pakde.

Kula ken pados data kefatisan nggen keluarga bangsawan.

[Well, my friend and I were recommended to get data from Uncle. I was asked to get data of phatic language on the noblemen.]

Interlocutor: Walah... bangsawan. Bangsawan tangine awan, yo to...hehe.

[Ow...nobleman. A nobleman wakes up late, right...hehe.] 
Speaker: Om Cip niku ngendika ngaten, "Iho Iho kok adoh-adoh", ngoten tho.

[Uncle Cip said this, "Iho lha kok jauh-jauh" - "oh, why so far," is

he?]

"Lha wong enek sing cedhak kok golek sing adoh" ngoten. Criose wau ndalu mekaten.

["Oh, there are people who are close; why look that far away?"

he said last night]

Interlocutor: Nggih....monggo. Mudah saja!

[Yes...please. Easy!]

In this excerpt, the phatic form appears in the utterance "Wolah... bangsawan. Bangsa tongine awan, yo to...hehe.' [Ow...nobleman. Bangsa bangunnya siang-A nation wakes up late right...hehe.] At a glance, this excerpt is only a joke, but in reality it contains a phatic intention. The footage of the speech also begins with a phatic marker, "walah," which is actually intended to "break the silence" because previously there was a certain speech and no response has been submitted. Thus, it can be asserted that the linguistic form is not an interjection because there is no particular communicative purpose contained in the word. Therefore, it can be stated that such a linguistic form is purely a word in the phatic category, not a word in the interjective category $[6,12]$.

Similarly, when partners say to make a kind of word for "nobleman" becomes "bangsawan tangine awan," which means "nobleman wakes up late," it is not at all meant to show the real intention. There is also no purpose of insinuation or perhaps the dubious intent of humiliating in the linguistic form. The use of the word "nobility" is solely meant to break the silence, so that communication can be transmitted fairly. Furthermore, at the end of the footage there is the form of speech "Nggih....monggo. Mudah saja!" [Yes...please. Easy!]. The footage of the speech also begins with the phatic word "nggih," which in Indonesian means "yes." However, the word "yes" in the excerpt is not "yes" in the sense of "agreeing" or "affirming" a linguistic intention, but "yes" is merely a marker of phatic language. Such a form of language sometimes becomes the leap of a speech intention, i.e. from previous speech to later speech [2].

Furthermore, let us examine the phatic intent in the following excerpts. The following tutorial occurred at a restaurant on the beach. The dialogue took place between a shop owner and a student. 


\section{Data 2}

Restaurant owner: Nggih Mbak (Indonesian suffix (commonly used in Javo Island) refers to young maiden or unmarried woman) mangkih dimasakke.

[Yes, Miss. It will be cooked soon]

Student: Hehe...ning kekathahen niku Pak.

[Hehe...but it's too much, Sir.]

Restaurant owner: Dibakar boleh Mbak, nanti nek nggak habis dibungkus dibawa pulang.

[Roasted is OK, if it is not finished, it will be brought home.]

Fisherman: Lha, kan bisa dibungkus nggo calon morotuane.

[Ow, it can be wrapped for your prospective in-laws, right.]

Student: Lha belum ada calon e Pak. Calon aja belum punya masak udah punya mertua.

[Ow, I do not have a candidate yet. No candidate yet, let alone in-laws.]

Fisherman: Ha yo sama aku ajalah kalau nggak punya, Mbak.

[I can be your spouse if do not have any yet, Miss.]

Restaurant owner: lya Mbak, nanti kalau nggak habis dibungkus saja ya.

[All right, Miss, if the food is not finished then wrap it.]

In the excerpt from the above speech there are several words categorized as phatic. These words have no lexical meaning, but are very useful for initiating a conversation (Rahardi, 2017b). These linguistic forms are "nggih" in the speech footage such as in "Nggih Mbak mangkih dimasakke" [Yes, Miss. It will be cooked soon], "hehe..." in speeches like "Hehe...ning kekathahen niku Pak," and the form "Iha kan" in a speech like "Lha kan bisa dibungkus nggo calon morotuane" [OW, it can be wrapped for your prospective in-laws, right] and "Iha" in the utterance "Lho belum ada calon e Pak. Calon aja belum punya masak udah punya mertua" [Ow, I do not have a candidate yet. No candidate yet, let alone in-laws]. The last phatic marker that appears in the above description is "Ha yo sama aku ajalah kalau nggak punya, Mbak" [I can be your spouse if do not have any yet, Miss]. 
Thus, it can be said that in various speech excerpts, the words are in the category of phatic that many emerge. The main purpose of the use of such words is to make the partners say fellow to other speakers in the real sense. If one party feels a partner and becomes a partner for the other in the communication process, it can be ensured that the communication is going well. In terms of the togetherness between speakers and partners it is said that there is a need to work together to maintain the process of communication [2]

Therefore, no one party will let a speech stop in the middle of the speech; if it happens that the good ongoing process of communication stops in the middle of a speech, it means that the idea of unity in togetherness is not applied at all [2]. In such a context, the presence of phatic language in speech becomes very important. Every citizen with a particular cultural background has specific and distinctive ways of maintaining that communication. In other words, the manifestation of phatic language also differs among people with a particular cultural background and other cultural backgrounds. It is in this context that it becomes very important to examine and scrutinize pragmatism in the sense of a specific culture.

\section{Conclusion}

In concluding this study of phatic language from the perspective of a specific culture in the vehicle of internationalization of this language several things can be affirmed as follows:

1. The phenomenon of phatic language is present in various utterances and spheres. In other words, phatic language as a pragmatic phenomenon present in the research data is abundant. It is asserted that phatic language is a universal phenomenon, which can be present in various speeches and also in various aspects and spheres of life.

2. Phatic speech is usually preceded by words categorized as phatic. The phatic category is not the same as interjections because the words in the phatic category have no particular lexical meaning. Unlike the interjections that can be included in a particular word class, the phatic form cannot fit in any word category.

3. In a speech, the manifestation of phatic language usually appears at the beginning of the speech. However, it is also possible that phatic language may be present in the middle and at the end of the speech. If present at the beginning of the speech, its function is to initiate the conversation or break the silence so that 
it is possible to speak, while if present at the end of the speech, its function is to end the conversation so that the communication is established and will certainly going well because the speech ends with no obstacles.

4. The results of this phatic language research also confirm that within specific cultural contexts, the manifestation of phatic language can be present with various manifestations. This confirms that language research based on Western culture and language does not always describe the phenomenon of widespread phatic language. The researcher wishes to affirm that such linguistic studies typically have very limited data, so the results are not sufficient to build linguistic principles.

\section{References}

[1] Rahardi RK, Setyaningsih Y, Dewi RP: Kata fatis penanda ketidaksantunan pragmatik dalam ranah keluarga. Adabiyyat. 2015; 13(2): 149-175.

[2] Rahardi K: Menemukan Hakikat Konteks. Surakarta: Universitas Negeri Surakarta; 2015.

[3] Greenfell L: Nationalism and Language. Amsterdam: Elsevier; 1998.

[4] Sperber D, Deirdre W: Relevance: Communication \& Cognition. USA: Blackwell Publishers; 1981.

[5] DuBois JW: Pragmatic Universals. Amsterdam: Elsevier; 1998.

[6] Rahardi RK: Menemukan Hakikat Konteks. In Haryato et al. (Eds.). Kajian Pragmatik dalam Berbagai Perspektif. Surakarta: Graduate Program, State University of Surakarta; 2015.

[7] Abercrombie D: Phatic Communion. Amsterdam: Elsevier; 1998.

[8] Kridalaksana H: Kelas Kata dalam Bahasa Indonesia. Jakarta: PT Gramedia; 2008.

[9] Richards J, John P, Heidi W: Longman Dictionary of Applied Linguistics. London: Longman; 1985.

[10] Leech, Geoffrey N: The Principles of Pragmatics. Oxford: Longman; 1983.

[11] Poedjosoedarmo S: Filsafat Bahasa. Surakarta: Muhammadiyah University Press; 2001.

[12] Allan K: Linguistic Meaning. London: Routledge \& Kegan Paul; 1986. 